\title{
Academic success: Which factors contribute signify- cantly to NCLEX-RN success for ASDN students?
}

\author{
Barbara B. Penprase, Meghan Harris, Xianggui Qu \\ Department of Mathematics and Statistics, School of Nursing, Oakland University, Rochester, USA \\ Correspondence: Barbara B. Penprase. Address: 2002 HSB, School of Nursing, Oakland University, Rochester, MI \\ 48309, USA. Email: Penprase@oakland.edu.
}

Received: September 14, 2012

Accepted: September 23, 2012

Online Published: January 9, 2013

DOI : $10.5430 /$ jnep.v3n7p1

URL: http://dx.doi.org/10.5430/jnep.v3n7p1

\section{Abstract}

Background: Accelerated Second Degree Nursing (ASDN) programs have become a vital means of addressing the nursing shortage resulting in a sharp increase in the number of these programs. In 2009, there were 230 accelerated programs and 33 in formal planning stages. Yet there has been little research to understand the predictive value of key components of these nursing programs for academic achievement as demonstrated by NCLEX-RN success. The purpose of this study was to determine the most significant factors and predictive value of these factors as they relate to student success on NCLEX-RN in an ASDN program.

Methods: A retrospective predictive correlational design was employed to examine relationships between performance in pre-nursing and nursing courses as well as standardized tests for 363 ASDN students and NCLEX-RN success. A significance level of 0.05 was maintained for the analyses in this study.

Results: The research results showed a high correlation with the first Medical/Surgical course as well as the pre-nursing course, Pathophysiology and offers new insight that is important in early identification of ASDN students who may or may not be successful on NCLEX-RN. More importantly, it sheds light on the factors, such as specific nursing courses, that best prepare ASDN students for RN-NCLEX success.

Conclusion: The research results offer new insight that is important in early identification of ASDN students who may not be successful on NCLEX-RN. More importantly, it sheds light on the factors, such as specific nursing courses, that best prepare ASDN students for NCLEX-RN success.

\section{Key words}

Accelerated Second Degree Nursing, Accelerated Second Degree Nursing Programs, NCLEX-RN

\section{I ntroduction}

Accelerated Second Degree Nursing (ASDN) programs are vital to addressing the nursing shortage which has resulted in a sharp increase in the number of these programs. In 2009, there were 230 accelerated programs and 33 in formal planning stages ${ }^{[1]}$. ASDN programs attract a new population of students to the nursing profession. ASDN programs are exclusive to college graduates that have completed science and liberal arts requirements, and have life experience from which to draw ${ }^{[2]}$. Indeed, these programs are designed to capitalize on the student's prior experience and learning, recognizing that 
students come to the program as adult learners ${ }^{[3]}$. ASDN students adapt easily into the rapid transition of the nursing profession; the majority of these programs only taking between 11 and 18 months to complete the ASDN program ${ }^{[4]}$.

NCLEX-RN pass rates are one common measure used to evaluate the success of baccalaureate nursing programs. As such, researchers have begun to identify key factors that can predict the success of ASDN students on this measure, as well as students' overall grade point average (GPA) and scores on various standardized tests ${ }^{[5,6]}$. However, there is little research to understand the predictive value of key components of nursing programs for academic achievement as demonstrated by NCLEX-RN success.

The purpose of this study was to explore the relationship between ASDN students' performance in nursing, pre-nursing courses and on standardized tests as related to success on the NCLEX-RN. An extensive review of literature in the area of ASDN was conducted in CINAHL and Medline databases. This revealed an increase in research in this area but little specific to curricular components and their contribution to students' success.

\section{Literature review}

The past ten years have seen an abundance of research exploring ASDN programs ${ }^{[7-12]}$. These studies have used varying definitions of success. There is strong evidence that ASDN students usually excel, though studies widely vary in their findings. Researchers have reported NCLEX-RN first-attempt pass rates for ASDN students as high as $95 \%{ }^{[13]}$ and as low as $84.2 \%{ }^{[14]}$. However, much of the research focused on comparison between ASDN and traditional nursing students and programs, demographics and program admission criteria. Only one research study was found that focused on evaluation of curricular components in predicting success on NCLEX-RN.

The literature centered on factors that may predict successful outcomes for ASDN students is sparse. There is evidence that higher GPAs and high scores on standardized tests predict higher NCLEX-RN pass rates with regards to ASDN students ${ }^{[15-17]}$, but this is true for all nursing students ${ }^{[18-23]}$.

Although much research has been published about ASDN programs and nursing students in general, there is little that specifically understands predictive clues that can help these programs identify areas of strength and weakness within curricula to better prepare nursing students for the rigor of the accelerated pace. Abele, Penprase, and Ternes ${ }^{[24]}$ identified that a fundamental psychology course, taken either as a prenursing course or in the first year of the nursing curriculum, had significant correlation with success on first-time NCLEX-RN pass rates and success in graduating from their nursing program but this included traditional nursing students not specific to ASDN students. No other courses were identified as factors that contributed to success in graduating from nursing and NCLEX-RN pass rates. A limitation to this study was that they did not look specifically at ASDN students, and the sample only included students who were on probation or had been dismissed from the nursing program.

There is significant research that examines nursing students who are at academic risk related to personal background preparation, pre-entrance examinations, GPA in nursing programs, and NCLEX-RN preparation examinations; but many of those that include ASDN programs often did so by comparing traditional baccalaureate nursing students with ASDN students ${ }^{[25,26]}$. These studies support that ASDN do as well as, and often better than, traditional nursing students.

The focus of this research is to fill the gap of understanding predictive factors of student performance in ASDN curriculum on NCLEX-RN success. Additionally, the study identifies areas of students' strengths and weaknesses within curricula to better prepare ASDN nursing students for the rigor of the accelerated pace. This study's findings are important for nurse educators in two main ways. First, the types of courses (nursing and non-nursing) that are most closely associated with NCLEX-RN success can be identified and strengthened. Second, students who are at risk of NCLEX-RN failure can be identified early in the nursing program or while taking pre-requisites through their performance in these key courses. This 
study differs from other research in that it examines ASDN nursing programs' prerequisites as well as nursing courses, and in that it offers insights into the curriculum based on student performance over several years.

\section{Methods}

A retrospective predictive correlational design was employed to examine relationships between performance in prenursing and nursing courses as well as standardized tests for ASDN students and NCLEX-RN success. This research study was conducted at a large Midwestern nursing school that implemented an ASDN program in 2005. The program is completed in 12 months ( 1 year) and all students attend full time. The students must take all pre-requisites, including three nursing courses (Nutrition, Pathophysiology and Pharmacology) before they can begin the program (see Table 1). The ASDN program varies considerably from the traditional baccalaureate nursing program which will admit students directly into the nursing program from high school. Thus, many traditional students may take all the pre-requisites as well as nursing courses while in the nursing program whereas the ASDN take all pre-requisite courses before starting the nursing curriculum. Time varies as to when the pre-requisite courses are taken for the ASDN but averages two years from start date of nursing program. Many of the pre-requisites, especially the Psychology Across the Life Span and Philosophy, are taken at our University within a year of starting the curriculum whereas other courses frequently are taken at other universities or community colleges. Data was collected for 363 students who had graduated from the ASDN program between the years 2006 through 2009. The study was deemed exempt by the institutional IRB review board at this university.

Table 1. Plan of Study for ADSN Program

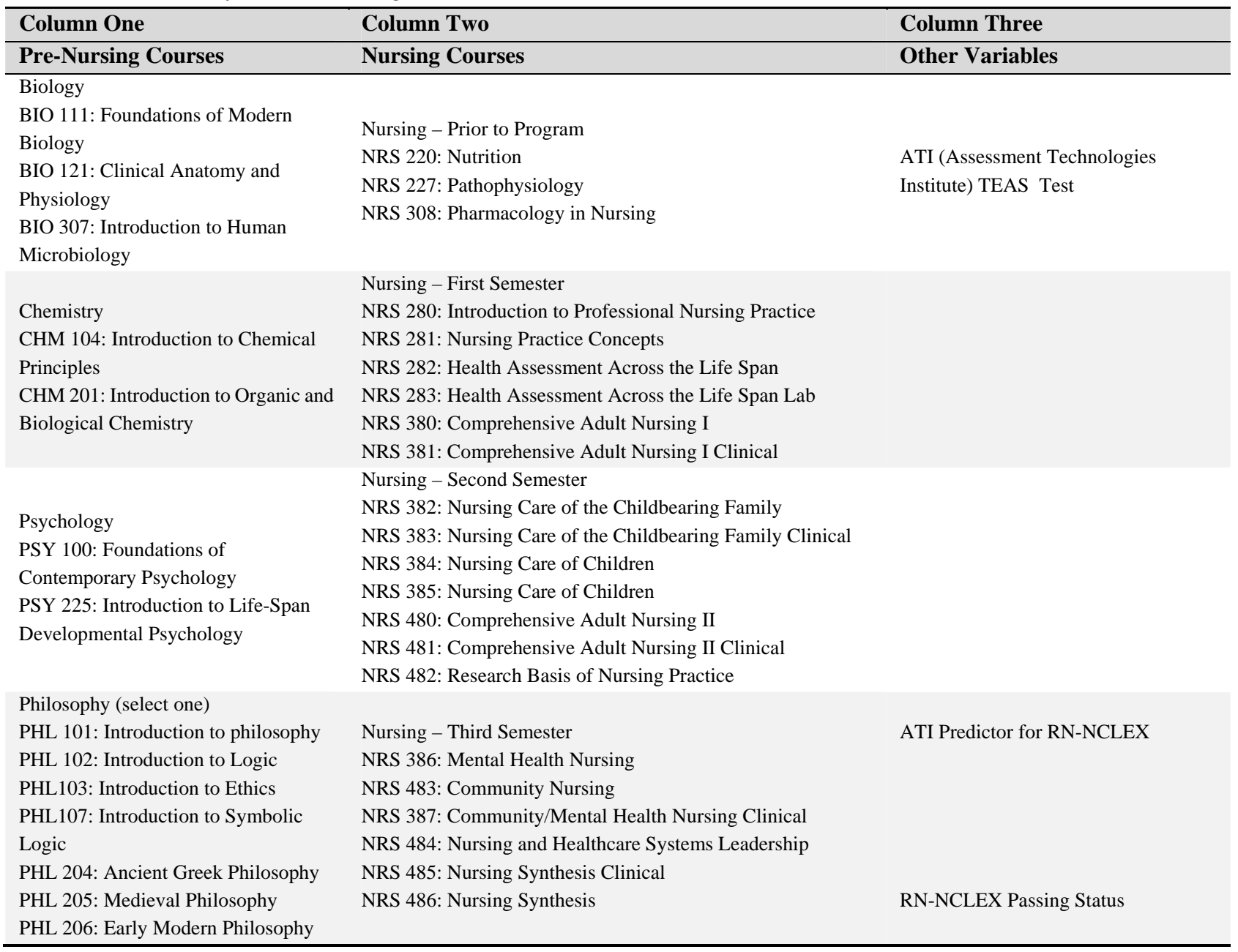


The primary measure was the students' final grades (scale of 0 to 4.0) for each of 30 courses, including 22 nursing courses and 8 prerequisites. The other measures were students' scores on standardized tests by Assessment Technology Institute (ATI). One was for a baseline assessment using Test of Essential Academic Skills (TEAS) as an academic predictor and the second was the NCLEX-RN Predictor examination. Standardized test like TEAS and NCLEX-RN predictor are used to assist in predicting academic achievement in nursing school (TEAS) and also NCLEX-RN pass rates (NCLEX-RN Predictor). The TEAS test is taken at the beginning of the ASDN program within four weeks from starting the nursing curriculum; it tests in areas of grammar, basic math skills, English comprehension and writing, and basic science. There is no incentive to do well on this test such as a grade or admission into school. The NCLEX-RN predictor serves to forecast how students will perform on NCLEX-RN, is given approximately seven weeks into the final semester of the program. If students were not successful on this test, they would continue into a remediation period for six weeks and then another NCLEX-RN predictor examination would be given. After administration of these standardized examinations, they are returned to ATI for scoring. ATI then provides Web-based diagnostic reports regarding student performance on the tests, including an overall composite score and composite scores based on national averages (http://www.atitesting.com).

NCLEX-RN passing status, defined as notification that the student had passed the exam from the state licensure department on the first attempt was used to determine success; thus, students who did not complete the nursing program or who failed the NCLEX-RN on their first attempt were treated as failing.

The student outcomes were extracted from student records without the students' names or other identifying information. The primary researcher was responsible for data collection and entry.

\section{Results}

The 363 students had a mean age of 33 years. The sample was predominately female (82\%) and Caucasian (76\%). The proportion of men in the program, $18 \%$, was notably higher than the national average of $10.8 \%$ in all BSN programs ${ }^{[27]}$ (AACN, 2010). Overall, 88\% of the ASDN students in the sample passed the NCLEX-RN on their first attempt (range of cohorts from 77\% to 98\%). The ASDN students performed better on the NCLEX-RN than the traditional students from the same nursing school, consistent with previous findings that ASDN students outperform traditional students on the NCLEX-RN ${ }^{[28-30]}$. The ASDN program attrition rate for this sample was approximately $14 \%$, consistent with findings of other studies ${ }^{[31]}$. Statistical analysis was done by bestglm package in statistical software R. The odds ratios of all selected variables and their 95\% confidence intervals are given in Table 2.

Table 2. Odds ratio and their 95\% confidence intervals

\begin{tabular}{llllllll}
\hline Variable & Estimate & Std. Error & z value & $\boldsymbol{p}$ value & Odds ratio & 95\% confidence interval \\
\hline GPA & 2.113 & 1.086 & 1.945 & 0.052 & 8.269 & 1.108 & 87.197 \\
BIO 111 & -0.167 & 0.608 & -0.275 & 0.783 & 0.846 & 0.25 & 2.604 \\
CHEM 104 & 0.054 & 0.637 & 0.085 & 0.932 & 1.056 & 0.272 & 3.257 \\
CHEM 201 & 1.19 & 0.766 & 1.552 & 0.121 & 3.286 & 0.798 & 17.675 \\
Philosophy & -1.453 & 0.944 & -1.539 & 0.124 & 0.234 & 0.027 & 1.171 \\
NRS 227 & 2.131 & 1.27 & 1.677 & 0.094 & 8.422 & 0.887 & 149.594 \\
NRS 380 & 4.624 & 1.601 & 2.888 & 0.004 & 101.924 & 5.566 & 3463.003 \\
ATI Exam & 0.175 & 0.077 & 2.273 & 0.023 & 1.192 & 1.037 & 1.414 \\
\hline
\end{tabular}

According to our analysis, NRS 380 (Comprehensive Adult Nursing I) contributed the most to the odds ratio of passing the NCLEX-RN. In this course, the probability of passing the NCLEX-RN increased by $59 \%$ for every 0.1 increase in a student's grade (scale of 0-4.0). For example, the student who received a grade of 3.4 in the NRS 380 class had a 59\% better chance of passing the NCLEX than the student who performed at 3.3. Just as important is that NRS 380 was by far 
the best predictor of how a student was do perform on NCLEX-RN in relationship to any other courses, GPA, TEAS and NCLEX-RN Predictor. NRS 227 (Pathophysiology) contributed the second most, increasing the probability of passing NCLEX-RN by $24 \%$ for every increase of 0.1 in a student's grade (scale $0-4.0$ ). Again, if a student had a 3.5 in the class, she/he would have a $24 \%$ higher chance of passing the NCLEX-RN than the student with a 3.4. But emphasis is really centered on the fact that NRS 227 serves as a strong predictor to NCLEX-RN first-time pass rates over the other factors other than NRS 380. Overall GPA (scale of 0-4.0) followed close behind, increasing the probability of passing NCLEX-RN by $23 \%$ for every increase of 0.1 . Next was the NCLEX-RN predictor examination, which increased the probability of passing the NCLEX-RN by $20 \%$ for every percent increase in the student's mark (average percentage of all students who took the NCLEX-RN predictor). Finally, CHEM 201 (Organic and Biological Chemistry) and CHEM 104 (Introduction to Chemical Principles) increased the odds ratio by $13 \%$ and $0.5 \%$, respectively, for every increase of 0.1 in a student's grade (scale of 0-4). Interestingly, Philosophy and BIO 111 (Foundations of Modern Biology) were inversely related to success on the NCLEX-RN.

\section{Discussion}

Of all the courses in the ASDN program under study, Comprehensive Adult Nursing I is the most strongly related to a student's probability of passing the NCLEX-RN. This course focuses on competencies for nursing care assessment and management of adult clients and their families through integration of theory and specific nursing interventions appropriate to acute and chronic illness. It includes content related to adults in perioperative care, the immunological, respiratory, and cardiovascular systems, fluid and electrolytes, and geriatric clients. This content is taught in the second half of the first semester as the students begin their first clinical rotation. Although the findings indicate a probability of passing NCLEX$\mathrm{RN}$ when performing well in this class compared to several other variables, there is no question that earning a high grade in this key course, reflecting mastery of this important medical/surgical material, contributes significantly to successful performance on the NCLEX-RN. Although Medical/Surgical Nursing courses have been found to be correlated with NCLEX-RN success with traditional students ${ }^{[33,34]}$, there are no studies that are specific to ASDN students, nor show as great of a significance. Moreover, this finding suggests that because this course is given so early in the curriculum, it can be used to identify students early in the nursing program who may struggle with critical thinking and the application of nursing concepts to practice.

The pathophysiology course also makes a considerable contribution ( $24 \%$ for every grade point increase of 0.1 ) to the odds ratio of the ASDN student passing the NCLEX-RN. It is the basic pathophysiology course required for ASDN students. Cambell ${ }^{[35]}$ found similar findings in her research for traditional nursing students. This course is taken as a prerequisite to the nursing program and the content of this course makes its relationship with success on the NCLEX-RN logical. Students with a firm base in pathophysiology are better prepared to make sound clinical decisions. These results are the first to indicate that nursing students benefit from mastering the pathophysiology content prior to beginning the rigors of the ASDN program. The findings further suggest that simply integrating pathophysiology content into other nursing courses may not be the best approach for students' academic success.

The basic chemistry courses, Introduction to Organic and Biological Chemistry and Introduction to Chemical Principles, make modest contributions to the odds ratio of ASDN students' success on the NCLEX-RN ( $0.5 \%$ and $13 \%$, respectively, for every grade point increase of 0.1). Students must pass these courses before entering the nursing program, making them early building blocks for a sound nursing education. However, some nurse educators have questioned the necessity of requiring two chemistry courses, especially as programs need to incorporate new courses such as informatics and genetics, to meet the challenges of accreditation. While more research is needed, the current findings suggest that the two chemistry courses do indeed play a role in ensuring adequate preparation of students for the nursing curriculum.

The study's findings support previous research in showing that overall GPA is a sound predictor of students' success for NCLEX-RN success ${ }^{[36-38]}$. For every increase in GPA of 0.1 , the odds of passing the NCLEX-RN increased by $23 \%$ for 
the ASDN students in this study's sample. The ATI RN Predictor Examination also made a sizable contribution to success on the NCLEX-RN, with the probability of passing the NCLEX-RN increasing by $20 \%$ for every percent increase in the ATI RN Predictor score. Although results of this study validate previous findings with traditional nursing students ${ }^{\text {[39-42] }}$, these are the first reported results for ASDN programs regarding the significant relationship between the ATI RN Predictor Examination and success on the NCLEX-RN examination. However, this study did not support that the TEAS served as a predictor for success on NCLEX-RN examination as several other studies have found ${ }^{[43-45]}$.

Interestingly, two courses in our program - Philosophy and Foundations of Modern Biology (BIO 111) - show inverse relationships with NCLEX-RN success. It can be surmised that the general content in a basic philosophy course is not critical to nursing practice at the entry level. This course has been the subject of repeated debate among our faculty as to its relevance to the overall preparation of nursing students. The current study offers the first evidence-based support for faculty assumptions that the Philosophy course is not highly valuable to the nursing curriculum and indicates that a thorough understanding of the impact of required courses may help faculty identify opportunities for change and improvement.

There are limitations to this study. The sample was predominately Caucasian females; however, this demographic makeup reflects the general population of nursing students throughout the United States. Additionally, the data reflect only one group of nursing students in a Midwest university and cannot be generalized to all ASDN programs.

\section{Conclusion}

It is important that all nursing programs evaluate the success of their graduating students. Students spend significant money and time to complete a BSN program. For ASDN students, this is in addition to their already completed degree. Many ASDN students are older, have families and are on fixed incomes, so the commitment of time, energy and resources can be overwhelming, especially in this Midwestern state where the economic decline has had a major impact on unemployment and underemployment. Understanding key factors that can help predict student success prior to, or early in, the program should improve students' overall performance, assist faculty to identify at-risk students, reduce attrition, and raise pass rates on the NCLEX-RN examination.

\section{References}

[1] American Association of Colleges of Nursing (AACN). Available from: http://www.aacn.nche.edu/media/factsheets/acceleratedprog.htm (12 September 2012, date last accessed).

[2] Rico S, Beal J, Davies T. Promising practices for faculty in accelerated nursing programs. Journal of Nursing Education. 2010; 49(3): 150-155. PMid:20143760 http://dx.doi.org/10.3928/01484834-20100115-01

[3] Penprase B, Koczara S. Understanding the Experiences of Accelerated Second-Degree Nursing Students and Graduates: A Review of the Literature. The Journal of Continuing Education in Nursing. 2010: 40(2): 74-79.

[4] American Association of Colleges of Nursing (AACN). http://www.aacn.nche.edu/media/factsheets/acceleratedprog.htm (12 September 2012, date last accessed).

[5] Seldomridge LA, DiBartolo MC. A profile of accelerated second bachelor's degree nursing students. Nurse Educator. 2005; 30(2): 65-68. PMid:15785342 http://dx.doi.org/10.1097/00006223-200503000-00007

[6] Shiber SM. A nursing educational model for second-degree students. Nursing Education Perspectives. 2003; 24(3): 135-138. Cangelosi PR. Accelerated nursing students and theater students: creating a safe environment by acting the part. Nursing Education Perspectives. 2008; 29(6): 342-346.

[7] Aktan NM, Bareford CG, Bliss JB, Connolly K, DeYoung S, Sullivan KL, et al. Comparison of outcomes in a traditional versus accelerated nursing curriculum. International Journal of Nursing Education Scholarship. 2009; 6(1): 1-11. PMid:19409069 http://dx.doi.org/10.2202/1548-923X.1639

[8] Bentley R. Comparison of traditional and accelerated baccalaureate nursing graduates. Nurse Educator. 2006; 31(2): 79-83 PMid:16601615 http://dx.doi.org/10.1097/00006223-200603000-00010 
[9] Penprase B, Koczara S. Understanding the Experiences of Accelerated Second-Degree Nursing Students and Graduates: A Review of the Literature. The Journal of Continuing Education in Nursing. 2010: 40(2): 74-79.

[10] Rico S, Beal J, Davies T. Promising practices for faculty in accelerated nursing programs. Journal of Nursing Education. 2010; 49(3): 150-155. PMid:20143760 http://dx.doi.org/10.3928/01484834-20100115-01

[11] Seldomridge LA, DiBartolo MC. A profile of accelerated second bachelor's degree nursing students. Nurse Educator. 2005; 30(2): 65-68. PMid:15785342 http://dx.doi.org/10.1097/00006223-200503000-00007

[12] Shiber SM. A nursing educational model for second-degree students. Nursing Education Perspectives. 2003; 24(3): 135-138. PMid:12830684

[13] Shiber SM. A nursing educational model for second-degree students. Nursing Education Perspectives. 2003; 24(3): 135 -138.

[14] Seldomridge LA, Di Bartolo MC. A profile of accelerated second bachelor's degree nursing students. Nurse Educator. 2005; 30(2): 65-68. PMid:15785342 http://dx.doi.org/10.1097/00006223-200503000-00007

[15] Bentley R. Comparison of traditional and accelerated baccalaureate nursing graduates. Nurse Educator. 2006; 31(2): 79-83. PMid:16601615 http://dx.doi.org/10.1097/00006223-200603000-00010

[16] Seldomridge L, DiBartolo M. Can success and failure be predicted for baccalaureate graduates on the computerized NCLEX-RN?. Journal of Professional Nursing? Journal of Professional Nursing. 2004; 20(6): 361-368. PMid:15599869 http://dx.doi.org/10.1016/j.profnurs.2004.08.005

[17] Seldomridge LA, DiBartolo MC. A profile of accelerated second bachelor's degree nursing students. Nurse Educator. 2005; 30(2): 65-68. PMid:15785342 http://dx.doi.org/10.1097/00006223-200503000-00007

[18] Brown J, Marshall B. A historically Black university's baccalaureate enrollment and success tactics for registered nurses. Journal of Professional Nursing. 2008; 24: 21-29. PMid:18206839 http://dx.doi.org/10.1016/j.profnurs.2007.06.006

[19] Newton S, Moore G. Use of Aptitude of understand Bachelor of Science in Nursing Student Attrition and Readiness for the National Council Licensure Examination-Registered Nurse. Journal of Professional Nursing. 2009; 25(5): 273-278. PMid:19751931 http://dx.doi.org/10.1016/j.profnurs.2009.01.016

[20] Newton S, Smith L, Moore G. Baccalaureate nursing program admission policies: Promiting success or facilitating failure? Nurse Educator. 2007; 33: 45-48. PMid:18091472 http://dx.doi.org/10.1097/01.NNE.0000299498.30743.5e

[21] Newton S, Smith L, Moore G, Magnan M. Predicting Early Academic Achievement in A Baccalaureate Nursing Program. Journal of Professional Nursing. 2007; 23(3): 144-149. PMid:17540317 http://dx.doi.org/10.1016/j.profnurs.2006.07.001

[22] Seldomridge L, DiBartolo M. Can success and failure be predicted for baccalaureate graduates on the computerized NCLEX-RN? Journal of Professional Nursing? Journal of Professional Nursing. 2004; 20(6): 361-368. PMid:15599869 http://dx.doi.org/10.1016/j.profnurs.2004.08.005

[23] Seldomridge LA, DiBartolo MC. A profile of accelerated second bachelor's degree nursing students. Nurse Educator. 2005; 30(2): 65-68. PMid:15785342 http://dx.doi.org/10.1097/00006223-200503000-00007

[24] Abele C, Penprase B, Ternes R. A closer look at academic probation and attrition: What courses are predictive of nursing students' success? Nurse Education Today 2012. Online publication. http://dx.doi.org/10.1016/j.nedt.2011.11.017

[25] Bentley R. Comparison of traditional and accelerated baccalaureate nursing graduates. Nurse Educator. 2006 ; $31(2)$ : 79-83. PMid:16601615 http://dx.doi.org/10.1097/00006223-200603000-00010

[26] Ouellet L, MacIntosh J. The rise of accelerated baccalaureate programs. Canadian Nurs. 2007; 103(7): 28-31. PMid:17953156

[27] American Association of Colleges of Nursing (AACN). Available from: http://www.aacn.nche.edu/media/factsheets/acceleratedprog.htm (12 September 2012, date last accessed).

[28] Meyer G, Hoover K, Maposa S. A profile of accelerated BSN graduates. Journal of Nursing Education. 2006; $45(8)$ : 324-327. PMid:16915992

[29] Penprase B, Koczara S. Understanding the Experiences of Accelerated Second-Degree Nursing Students and Graduates: A Review of the Literature. The Journal of Continuing Education in Nursing. 2009; 40(2): 74-79. PMid:19263928 http://dx.doi.org/10.3928/00220124-20090201-08

[30] Seldomridge LA, Di Bartolo MC. A profile of accelerated second bachelor's degree nursing students. Nurse Educator. 2005; 30(2): 65-68. PMid:15785342 http://dx.doi.org/10.1097/00006223-200503000-00007

[31] Rosenberg L, Perraud S, Willis L. The value of admission interviews in selecting accelerated second-degree baccalaureate nursing students. Journal of Nursing Education. 2007; 46: 413-416. PMid:17912993

[32] Burns N,Grove S. The Practice of Nursing Research: Appraisal, Synthesis, and Generation of Evidence. New York: Saunders. 2009.

[33] Silvestri L. Self-efficacy and the predictors for NCLEX-RN(RTM) success for baccalaureate nursing students. Ph.D., University of Nevada, Las Vegas. Available from: 
http://huaryu.kl.oakland.edu/login?url=http://search.ebscohost.com/login.aspx?direct=true\&db=rzh\&AN=2011033266\&site=eho st-live Available from EBSCOhost rzh database.2010.

[34] Strayer RM. Variables predicting success in an advanced medical-surgical nursing course and the NCLEX-RN for pre-licensure baccalaureate nursing students. Ph.D., Temple University. Available from:

http://huaryu.kl.oakland.edu/login?url=http://search.ebscohost.com/login.aspx?direct=true\&db=rzh\&AN=2011468919\&site=eho st-live Available from EBSCOhost rzh database. 2010.

[35] Campbell WT. Improving nursing student progression to RN at Salisbury University (Maryland). Ed.D, University of Delaware. Available from:

http://huaryu.kl.oakland.edu/login?url=http://search.ebscohost.com/login.aspx?direct=true\&db=rzh\&AN=2009711895\&site=eho st-live Available from EBSCOhost rzh database.2006.

[36] Aktan NM, Bareford CG, Bliss JB, Connolly K, DeYoung S, Sullivan KL, et al. Comparison of outcomes in a traditional versus accelerated nursing curriculum. International Journal of Nursing Education Scholarship. 2009; 6(1): 1-11. http://dx.doi.org/10.2202/1548-923X.1639

[37] Seldomridge LA, DiBartolo MC. A profile of accelerated second bachelor's degree nursing students. Nurse Educator. 2005; 30(2): 65-68. PMid:15785342 http://dx.doi.org/10.1097/00006223-200503000-00007

[38] Shiber SM. A nursing educational model for second-degree students. Nursing Education Perspectives. 2003; 24(3): 135-138. PMid:12830684

[39] Brown J, Marshall B. A historically Black university's baccalaureate enrollment and success tactics for registered nurses. Journal of Professional Nursing. 2008; 24: 21-29. PMid:18206839 http://dx.doi.org/10.1016/j.profnurs.2007.06.006

[40] Newton S, Moore G. Use of Aptitude of understand Bachelor of Science in Nursing Student Attrition and Readiness for the National Council Licensure Examination-Registered Nurse. Journal of Professional Nursing. 2009; 25(5): 273-278. PMid:19751931 http://dx.doi.org/10.1016/j.profnurs.2009.01.016

[41] Newton S, Smith L, Moore G. Baccalaureate nursing program admission policies: Promiting success or facilitating failure? Nurse Educator. 2007; 33: 45-48. PMid:18091472 http://dx.doi.org/10.1097/01.NNE.0000299498.30743.5e

[42] Newton S, Smith L, Moore G, Magnan M. Predicting Early Academic Achievement in A Baccalaureate Nursing Program. Journal of Professional Nursing. 2007; 23(3): 144-149. PMid:17540317 http://dx.doi.org/10.1016/j.profnurs.2006.07.001

[43] Abbott A. Schwartz M, Hercinger, M, Miller, C, Foyt, M. Student issues. Predictors of success on National Council Licensure Examination for Registered Nurses for accelerated baccalaureate nursing graduates. Nurse Educator. 2008; 33(1): 5-6. PMid:18091462 http://dx.doi.org/10.1097/01.NNE.0000299489.07872.b0

[44] Newton S, Moore G. Use of Aptitude of understand Bachelor of Science in Nursing Student Attrition and Readiness for the National Council Licensure Examination-Registered Nurse. Journal of Professional Nursing. 2009; 25(5): 273-278. PMid:19751931 http://dx.doi.org/10.1016/j.profnurs.2009.01.016

[45] Newton S, Smith L, Moore G, Magnan M. Predicting Early Academic Achievement in A Baccalaureate Nursing Program. Journal of Professional Nursing. 2007; 23(3): 144-149. PMid:17540317 http://dx.doi.org/10.1016/j.profnurs.2006.07.001 